\title{
KONSEP PENDIDIK DAN METODE PEMBELAJARAN YANG HUMANIS MENURUT IBNU KHALDUN
}

\section{Kiki Sumber Rejeki}

Prodi Pendidikan Agama Islam, Fakultas Ilmu Sosial, Universitas Negeri Jakarta

E-mail:kikisumberrejeki@gmail.com

\section{Article Information}

Informasi Artikel

Naskah diterima: 15

Maret 2020

Naskah direvisi: 28 Maret 2020

Naskah disetujui: 5 April Maret 2020

Naskah dipublish: 10 April 2020

Keywords Education Concept, Humanisme, Ibnu Khaldun

Kata Kunci Konsep Pendidik Humanis, Pendidikan, Ibnu Kaldun
Abstact
This study aims to find out and analyze the concept of educators and humanist learning methods according to Ibn Khaldun in his book entitled "Muqaddimah". The concept of educators and methods of learning in question is the behavior of educators in providing teaching to learners. The meaning of humanist according to Ibn Khaldun is a teaching that contains elements of humanity according to his nature as a human being. The approach used in this research is qualitative descriptive by reviewing the book of Muqaddimah with publisher of Maktabah Al-Hidayah as primary source and translation book of Muqaddimah with publisher Pustaka Al-Kautsar as secondary source and other supporting book. This research produces some educational concepts and learning methods that are humanist according to Ibn Khaldun.

\section{Abstrak}

Penelitian ini bertujuan untuk mengetahui serta menganalisis konsep pendidik dan metode pembelajaran yang humanis menurut Ibnu Khaldun dalam bukunya yang berjudul "Muqaddimah". Konsep pendidik dan metode pembelajaran yang dimaksud adalah perilaku ataupun cara pendidik dalam memberikan pengajaran kepada peserta didik. Adapun yang dimaksud dengan humanis menurut Ibnu Khaldun adalah pengajaran yang mengandung unsur-unsur kemanusiaan sesuai fitrahnya sebagai manusia. Pendekatan yang dipakai dalam penelitian ini adalah kualitatif deskriptif dengan menelaah kitab Muqaddimah dengan penerbit Maktabah AlHidayah sebagai sumber primer dan buku terjemahan Muqaddimah dengan penerbit Pustaka Al-Kautsar sebagai sumber sekunder serta buku penunjang lainnya. Penelitian ini menghasilkan beberapa konsep pendidik dan metode pembelajaran yang humanis menurut Ibnu Khaldun. 


\section{PENDAHULUAN}

Saat ini telah banyak tokoh-tokoh pendidikan yang menerangkan mengenai berbagai macam teori maupun metode pendidikan yang dapat diterapkan sesuai dengan kebutuhan peserta didik, pendidik dan faktor-faktor lainnya, namun penulis memiliki ketertarikan dengan konsep pendidik dan metode pembelajaran yang dikemukakan oleh Ibnu Khaldun dalam kitabnya yang berjudul "Muqaddimah". Ibnu Khaldun (w.1406 M) sendiri merupakan salah satu tokoh muslim yang dikenal sebagai seorang ilmuan multidisiplin. Hal itu terlihat dari banyaknya bidang ilmu yang dikuasainya seperti filsafat, sufi, sejarah, ekonomi, sosiologi, hukum, politik hingga pendidikan. ${ }^{1}$

Hal y ang menarik dari kitab muqaddimah tersebut adalah konsep pendidik yang humanis dari perspektif Ibnu Khaldun. Menurut substansinya, Ahmad Nurul Kawakib ${ }^{2}$ mengungkapkan bahwa "teori humanistik sesuai dengan substansi pendidikan islam karena secara substansial pendidikan islam adalah pendidikan yang memandang manusia sebagaimana layaknya manusia, yaitu manusia ciptaan Allah SWT dengan dianugerahi fitrah tertentu untuk dikembangkan secara maksimal dan optimal. Dalam konteks ini fitrah diartikan sebagai kemampuan dasar manusia untuk berkembang”.

Adapun konsep pendidik yang humanis diantaranya adalah memberikan pengajaran sesuai dengan tingkat kesiapan pemahaman (isti'dad) peserta didik. Pendidik juga harus memperhatikan kebiasaan atau budaya ('adah) setiap wilayah, hal ini dikarenakan setiap wilayah memiliki metode ataupun cara mengajar yang berbedabeda. Pendidik juga harus mampu memaksimalkan potensi peserta didik dengan menanamkan dan menumbuhkan pemahaman yang sempurna (malakah). Selain itu, seorang pendidik juga harus memiliki sifat lemah lembut dan kasih sayang (almulayanah) dalam memberikan pengajaran terhadap peserta didik.

Selain membahas konsep pendidik yang humanis, Ibnu Khaldun juga membahas metode pembelajaran yang humanis seperti metode dengan pola gradual (tadrij) dan pengulangan (takrir). Dalam pola ini Ibnu Khaldun membagi pengajaran kepada tiga tahapan yaitu Sabilul Ijmal, Syarhul Bayan dan Takhallus. Ibnu Khaldun juga mengemukakan pentingnya metode lawatan (rihlah) kepada pendidik yang memiliki keahlian tertentu demi memaksimalkan pemahaman peserta didik tersebut.

\footnotetext{
${ }^{1}$ Ahma d Tarmiji, Pemikiran Pendidikan Ibnu Khaldun,(Bogor, Edukasi Press, 2011), h. 31

${ }^{2}$ Ahmad Nurul Ka wakib, Islam Moderat, (Malang: UIN-Maliki Press, 2016), h. 135.
} 
Terakhir, Ibnu Khaldun menganjurkan metode diskusi (munadzarah) demi melatih keaktifan berbicara peserta didik dalam mengemukakan pendapat mereka.

Dengan demikian, peran pendidik lebih sebagai mediator dan fasilitator yang meliputi: menyediakan pengalaman belajar, menyediakan atau memberikan kegiatankegiatan yang merangsang keingintahuan peserta didik dan membantu mereka untuk mengekspresikan gagasannya, serta memonitor, mengevaluasi dan menunjukkan apakah pemikiran siswa berjalan atau tidak. ${ }^{3}$

Adapun rumusan masalah yang ingin ditemukan dari penelitian tersebut adalah bagaimana konsep pendidik dan metode pembelajaran yang humanis menurut Ibnu Khaldun dalam karyanya yang berjudul "Muqaddimah". \Sedangkan tujuan dari penelitian ini adalah untuk mengetahui perilaku-perilaku pendidik serta metode-metode pembelajaran yang humanis di dalam kitab "Muqaddimah" tersebut.

Demi pengembangan ilmu pengetahuan khususnya di bidang kajian tokoh pendidikan islam dan pemikiran, semoga penelitian ini menjadi dokumentasi dan arsip tentang pendapat Ibnu Khaldun tentang konsep pendidikan humanis. penelitian ini juga diharapkan dapat berpartisipasi dalam memperkaya konsep-konsep Pendidikan Islam di Indonesia dan dapat dijadikan masukan untuk konsep pendidikan nasional pada saat ini.

\section{METODOLOGI PENELITIAN}

Penelitian ini menggunakan pendekatan kualitatif yang menekankan analisis proses dari proses berfikir secara induktif yang berkaitan dengan dinamika hubungan antar fenomena yang diamati, dan senantiasa menggunakan logika ilmiah. ${ }^{4}$

Dalam penelitian ini, penulis menggunakan teknik Analisis Isi (content analysis) dalam bentuk deskriptif yaitu berupa catatan informasi faktual yang menggambarkan segala sesuatu apa adanya dan mencakup penggambaran secara rinci dan akurat terhadap berbagai dimensi yang terkait dengan semua aspek yang diteliti. Maka, di sini penulis menggambarkan permasalahan yang dibahas dengan mengambil

\footnotetext{
${ }^{3}$ Eveline Siregar dan Hartini Nara, Teori Belajar dan Pembelajaran, (Bogor: Ghalia Indonesia, 2014), cet. III, h. 41.

${ }^{4}$ Imam Gunawan, Metode Penelitian Kualitatif, (Jakarta: Bumi Aksara, 2013), cet. I, h. 80.
} 
materi-materi yang relevan dengan permasalahan, kemudian dianalisis, dipadukan, sehingga dihasilkan suatu kesimpulan. ${ }^{5}$

Metode yang penulis gunakan dalam pengumpulan data adalah metode dokumentasi yaitu mencari data mengenai hal-hal atau variabel berupa buku-buku, jurnal, artikel, dan lain sebagainy a yang representatif, relevan dan mendukung terhadap objek kajian sehingga diperoleh jawaban yang dapat dipertanggung jawabkan dari permasalahan yang telah dirumuskan. Dokumen yang telah diperoleh kemudian dianalisis (diurai), dibandingkan dan dipadukan (sintesis) membentuk satu hasil kajian yang sistematis, padu dan utuh.

\section{KAJIAN TEORI}

Kata pendidik (guru) secara fungsional menunjukkan kepada seseorang yang melakukan kegiatan dalam memberikan pengetahuan, keterampilan, pendidikan, pengalaman, dan sebagainya. Istilah pendidik sering diwakili oleh istilah guru yang berarti orang yang bekerja dalam bidang pendidikan dan pengajaran yang ikut bertanggung jawab dalam membantu anak-anak mencapai kedewasaan masingmasing. ${ }^{6}$ Dari istilah tersebut, pendidik yang humanis dapat diartikan seseorang yang memberikan pengajaran peserta didik berupa pengetahuan, sikap dan keterampilan serta mengembangkannya sesuai dengan fitrahnya sebagai manusia secara maksimal dan optimal.

Adapaun konsep pendidik yang humanis meliputi; Menyesuaikan tingkat kesiapan (Isti'dad) pemahaman peserta didik. Memperhatikan kebiasaan atau budaya ('adah), Memperhatikan kebiasaan atau budaya ('adah), Menekankan pencapaian malakah, Menekankan pencapaian malakah.

Dari segi bahasa, metode berasal dari dua kata, yaitu kata "metha" yang berarti melalui dan kata "hodos" yang berarti jalan, dengan demikian metode berarti jalan atau cara yang harus dilalui untuk mencapai tujuan tertentu. Jalan mencapai tujuan ini bermakna untuk menemukan, menguji dan menyusun data yang diperlukan bagi

\footnotetext{
${ }^{5}$ Burhan Bungin, Penelitian Kualitatif: Komunikasi, Ekonomi, Kebijakan Publik, dan Ilmu Sosial Lainnya, (Ja karta: Kencana, 2008), Cet. 3, h. 155-159.

${ }^{6}$ Abuddin Nata dan Fauzan (eds), Pendidikan dalam Perspektif Hadits, (Ciputat: UIN Jakarta Press, 2005), cet. I, h. 207
} 
pengembangan ilmu. Dengan pengertian tersebut berarti metode lebih memperlihatkan sebagai alat untuk mengolah dan mengemban suatu gagasan. ${ }^{7}$

\section{KONSEP PENDIDIK YANG HUMANIS MENURUT IBNU KHALDUN}

1. Menyesuaikan tingkat kesiapan (Isti'dad) pemahaman peserta didik.

Ibnu Khaldun mengatakan bahwa "Apabila seorang pelajar pemula diberikan pengajaran yang seharusnya diberikan kepada para profesional sehingga membuatnya tidak mampu memahami dan menguasainya, dan jauh dari kesiapan pemikiran, sehingga dirinya akan merasa sulit memahami ilmu tersebut, maka hal itu akan membuatnya bermalas-malasan dan berusaha menghindarinya serta menyelewengkan pemahamannya". 8

Dari pernyataan Ibnu Khaldun diatas memberitahu bahwa seorang pendidik tidak diperbolehkan memberikan materi ataupun pengajaran kepada peserta didik yang tidak disesuaikan dengan kemampuan berfikir serta pemahaman mereka. Seandainya pengajaran tersebut tetap dilakukan, maka akan berdampak pada perkembangan peserta didik. Akibatnya mereka menjadi semakin tidak paham mengenai materi yang diajarkan dan akan menimbulkan banyak permasalahan lain seperti malasnya peserta didik terhadap materi tersebut, menghindarinya hingga menyelewengkan pemahaman yang tidak di mengerti tersebut.

Dalam pernyataan tersebut, Ibnu Khaldun juga membedakan antara pelajar pemula dengan profesional. Pelajar pemula yang dimaksud Ibnu Khaldun adalah para peserta didik yang masih belum memiliki pengalaman serta pemahaman sehingga butuh bimbingan untuk mencapai pemahaman dan pengalaman tersebut. Adapun profesional yang dimaksud adalah mereka yang sudah memiliki keterampilan atau keahlian (malakah) serta pengalaman dan pemahaman.

Dengan demikian, ada tiga hal yang dikemukakan oleh Ibnu Khaldun dalam mempengaruhi perkembangan dan pemahaman peserta didik, ketiga hal itu adalah pengalaman, usia dan mental. Pengalaman dapat mempengaruhi pemahaman karena dapat mendorong ataupun menghambat pemahaman mengenai hal yang pernah dialami sebelumnya. Usia menjadi salah satu aspek yang dapat mempengaruhi pemahaman

\footnotetext{
${ }^{7}$ Abuddin Na ta, Filsafat Pendidikan Islam, (Jakarta: Logos Wacana Ilmu, 1997), cet. I, h. 91.

${ }^{8}$ Ibnu Khaldun, Muqaddimah, Penerjemah Masturi Irhamdkk, (Jakarta: Pustaka Al-Ka utsar, 2011), h. 996.
} 
peserta didik karena usia menjadi indikator dalam mencapai tingkat kematangan dalam mengetahui sesuatu. Sedangkan mental dapat mempengaruhi pemahaman karena mental tersebut merupakan respon kejiwaan peserta didik dalam pengajaran yang diberikan oleh pendidik.

2. Memperhatikan kebiasaan atau budaya ('adah)

Ibnu Khaldun mengatakan bahwa "Dalam realitanya, masyarakat Hijaz lebih banyak meriwayatkan hadits dibanding masyarakat Irak. Sebab Madinah merupakan Darul Hijrah dan tempat bermukimnya para sahabat, sedangkan sahabat yang berhijrah ke Irak lebih banyak disibukkan dengan berjihad". ${ }^{9}$ Oleh karena itu Madzhab Maliki yang pada dasarnya menggunakan pendekatan Ahl Al-Hadits berkembang pesat di Madinah dan Madzhab Hanafi yang menggunakan pendekatan Ahl Ar-Ra'yi berkembang di Irak.

Dengan demikian, melakukan taklid kepada salah satu madzhab dari yang empat atau menyesuaikan madzhabnya dengan madzhab setempat akan memudahkan bagi pelajar yang ingin mempelajari inti dari masalah-masalah yang ada dalam kehidupan sehari-hari serta akan membuat mereka cepat paham dengan permasalahan tersebut karena mereka tidak harus mempelajari banyak istilah-istilah yang rumit dan sulit. Pandangan Ibnu Khaldun mengenai masalah madzhab dengan memperhatikan kebiasaan atau tradisi ('Adah) tersebut sesuai dengan pendekatan kontekstual pada saat ini.

Adapaun yang dimaksud dengan kontekstual adalah konsep belajar yang membantu pendidik mengaitkan antara materi yang diajarkan dengan situasi dunia nyata peserta didik dan mendorong mereka membuat hubungan antara pengetahuan yang dimilikinya dengan penerapannya dalam kehidupan. ${ }^{10}$

3. Menekankan pencapaian malakah

Ibnu Khaldun mengatakan bahwa "keahlian-keahlian yang terdapat dalam diri manusia sangatlah banyak seiring banyaknya aktivitas yang berkembang dalam peradaban. Keahlian-keahlian tersebut sangat bervariatif dan tidak terhitung

\footnotetext{
${ }_{9}^{9}$ Ibnu Khaldun, Muqaddimah, Penerjemah Masturi Irhamdkk, (Jakarta: Pustaka Al-Ka utsar, 2011), h. 822.

${ }^{10}$ Eveline Siregar dan Hartini Na ra, Teori Belajar dan Pembelajaran, (Bogor: Ghalia Indonesia, 2014), cet. III, h. 117
} 
jumlahnya". ${ }^{11}$ Dia juga mengatakan bahwa "Orang yang mempunyai bakat dan keahlian dalam suatu keahlian jarang sekali memiliki keahlian lainnya. Contoh dari pernyataan kami adalah seorang penjahit. Apabila seseorang mempunyai keterampilan menjahit yang sangat profesional dan menguasainya dengan baik, maka biasanya ia tidak memiliki keahlian lain setelahnya seperti pertukangan atau konstruksi bangunan kecuali jika keterampilan utama yang dimilikinya belum begitu profesional dan menguat". 12

Dengan demikian, dari pernyataan-pernyataan Ibnu Khaldun tersebut mengungkapkan bahwa sudah menjadi hal yang alamiah bahwa setiap manusia memilikibakatnya masing-masing. Namun untuk mengambangkan bakat terebut, perlu adanya pengajaran yang dilakukan secara berulang dan terus menerus oleh pendidik. Dalam hal ini, peran pendidik adalah sebagai mediator, fasilitator serta memonitor perkembangan peserta didik demi mencapai malakah mereka.

4. Memiliki sifat lemah lembut dan kasih sayang (Al-Mulayanah)

Ibnu Khaldun mengatakan bahwa "sikap keras dalam pendidikan dapat berakibat buruk bagi murid, apalagi ketika usianya masih kecil. Ini merupakan tabiat buruk. Barangsiapa yang tumbuh dalam kondisi pemaksaan dan penindasan, maka hal itu dapat membuatnya tidak bisa tumbuh dengan baik. Hal ini juga dapat membuatnya suka berbohong, pemalas dan perbuatan buruk lainnya". ${ }^{13}$

Dari pernyataan diatas, Ibnu Khaldun menekankan bahwa menunjukkan sikap keras kepada peserta didik terutama mereka yang masih anak-anak dan sedang dalam masa pertumbuhan akan berakibat buruk bagi mental peserta didik. Ibnu Khaldun menjelaskan lebih detail lagi bahwa jika peserta didik terus menerus tumbuh dalam kondisi seperti itu, maka akan terjadi hal-hal yang tidak diinginkan seperti suka berbohong, pemalas bahkan yang lebih parah dari itu.

Dengan demikian, pernyataan Ibnu Khaldun mengenai larangan bagi pendidik untuk bersikap keras kepada peserta didik karena akan berakibat fatal bagi perkembangan mental peserta didik di kemudian hari dan dalam jangka waktu yang

\footnotetext{
${ }^{11}$ Ibnu Khaldun, Muqaddimah, Penerjemah MasturiIrhamdkk, (Jakarta: Pustaka Al-Ka utsar, 2011), h. 739.

${ }^{12}$ Ibnu Khaldun, Muqaddimah, Penerjemah Masturi Irhamdkk, (Ja karta: Pustaka Al-Ka utsar, 2011), h. 737.

${ }^{13}$ Ibnu Khaldun, Muqaddimah, Penerjemah MasturiIrhamdkk, (Jakarta: Pustaka Al-Ka utsar, 2011), h. 1.007
} 
tidak sebentar. Padahal salah satu tugas dari seorang pendidik adalah menjadikan peserta didiknya menjadi pribadi yang memiliki budi pekerti luhur serta bermanfaat bagi sesama.

Oleh karena itu, Ibnu Khaldun menganjurkan kepada pendidik agar mengajar dengan gaya yang menyenangkan dan tidak membuat peserta didik merasa tertekan yaitu dengan mengutamakan sikap lemah lembut dan kasih sayang, namun tetap memperhatikan kebutuhan kasih sayang peserta didik dan pertumbuhan serta perkembangan mereka dalam mencapai pemahaman yang utuh.

Adapun bentuk kasih sayang yang bisa diterapkan oleh pendidik dalam mengajar menurut Ibnu Khaldun adalah sebagai berikut :

a. Pendidik memberikan pengajaran secara lemah lembut (al-mulayanah) sehingga membuat peserta didik merasa tertekan, terutama terhadap materi yang diberikan.

b. Pendidik menghargai setiap perbedaan pendapat yang diungkapkan peserta didik mengenai materi tersebut dalam metode diskusi (munadzarah)

c. Pendidik menumbuhkankesadaran kepada peserta didik dalam menggali makna dan pemahaman lebih dalam dari materi tersebut dengan menganjurkan untuk melakukan rihlah dll.

Dari berbagai pernyataan Ibnu Khaldun tersebut dapat dikatakan sesuai dengan prinsip-prinsip humanis, terutama cara pendidik dalam memberi pengajaran kepada peserta didik dengan mengedepankan lemah lembut dan kasih sayang. Hal ini dikarenakan fitrah mereka sebagai manusia yang butuh bimbingan dan arahan. Memberikan pengajaran dengan kasih sayang terhadap peserta didik juga terlihat lebih manusiawi daripada harus dengan sikap keras.

\section{KONSEP METODE PEMBELAJARAN YANG HUMANIS MENURUT IBNU KHALDUN}

Adapun metode pemebelajaran yang diungkapkan Ibnu Khaldun adalah sebagai berkut :

1. Metode Gradual (Tadrij) dan Pengulangan (Takrir)

Ibnu Khaldun mengatakan bahwa "mendiktekan atau menyampaikan ilmu pengetahuan kepada para penuntut ilmu sangat bermanfaat jika dilakukan secara 
bertahap, berangsur-angsur, dan sedikit demi sedikit, dengan memulai mengajarkan masalah-masalah mendasar dalam setiap bab dari ilmu pengetahuan". ${ }^{14}$

Dari pernyataan Ibnu Khaldun tersebut mengungkapkan bahwa pentingnya menyampaikan ilmu kepada peserta didik secara gradual atau tadrij yaitu berangsurangsur, bertahap, sedikit demi sedikit ketika mengajarkan masalah y ang mendasar. Adapun manfaat dan tujuan dari penerapan metode ini adalah agar peserta didik memiliki hasrat belajar serta memiliki pemahaman yang utuh mengenai pembelajaran tersebut. Disamping menggunakan metode gradual atau tadrij, Ibnu Khaldun juga menggunakan metode pengulangan atau dikenal dengan takrir. Alasan Ibnu Khaldun menggunakan kedua metode ini agar pemahaman peserta didik semakin terasah dan melekat. Oleh karena itu, Ibnu Khaldun membagi pengajaran kedalam tiga tahapan, yaitu :

Tahapan pertama yaitu penjelasan secara global (Sabilul Ijmal) "Mengajarkan masalah-masalah mendasar dalam setiap bab dari ilmu pengetahuan. Yakni, pokokpokok pembahasan bab tersebut, mendekatkan pemahaman, dan menjelaskannya secara global." 15

Pada tahapan pertama ini, hal utama yang perlu dilakukan oleh pendidik a dalah dengan memperhatikan kesiapan peserta didik untuk menerima pelajaran yang disampaikan hingga pembahasan akhir dari cabang ilmu tersebut serta menumbuhkan hasrat belajar mereka dengan pemberian motivasi didalamnya. Kesiapan yang dimaksud oleh Ibnu Khaldun adalah pengetahuan awal peserta didik mengenai materi tersebut, sehingga Ibnu Khaldun mengajarkan masalah-masalah yang dasar dan pokok dalam materi serta menjelaskan secara umum kepada peserta didik. Penjelasan secara umum disini adalah penjelasan dengan kata-kata, istilah ataupun ungkapan yang dapat dimengerti oleh peserta didik.

Adapun tujuan utama dari tahapan ini adalah untuk mempersiapkan peserta didik agar dapat memahamai cabang ilmu yang akan dipelajari dan memetakan masalah-masalah yang dibahasnya. Hal ini untuk menghindari permasalahan yang bercampur aduk dan tidak teratur, sehingga akan menyulitkan pemahaman peserta

\footnotetext{
${ }^{14}$ Ibnu Khaldun, Muqaddimah, Penerjemah Masturi Irhamdkk, (Ja karta: Pustaka Al-Ka utsar, 2011), h. 994.

${ }^{15}$ Ibnu Khaldun, Muqaddimah, Penerjemah MasturiIrhamdkk, (Jakarta: Pustaka Al-Ka utsar, 2011), h. 994.
} 
didik. Namun, dari fase ini peserta didik hanya akan memperoleh pemahaman sebagian saja dan masih terbatas sekali, oleh karena itu perlu adanya tahapan selanjutnya.

Selain itu, dalam tahapan ini Ibnu Khaldun juga mengisyaratkan pentingnya menumbuhkan hasrat belajar peserta didik. Hal ini dikarenakan tahap ini merupakan tahap yang krusial dan menentukan tahapan berikutnya. Jika peserta didik tidak memiliki hasrat belajar, maka tujuan pembelajaran pun akan sulit dicapai.

Tahapan kedua yaitu Penjelasan lanjutan (Syarhul Bayan) "Mengulangi pengajaran lagi yang kedua kalinya, dengan yang memberikan pengajaran yang lebih tinggi dari yang pertama, memberikan beberapa penjelasan dan keterangan lebih banyak, menguraikan poin-poin yang masih global, mengemukakan perbedaan pendapat dan disertai dengan pokok-pokok dasar perbedaannya hing ga keseluruhan cabang ilmu tersebut diuraikan". ${ }^{16}$

Dari pernyataan diatas, Ibnu Khaldun mencoba untuk meningkatkan pemahaman peserta didik pada tahapan pertama dengan mengkombinasikan pola gradual (tadrij) dengan pola pengulangan (takrir). Adapun yang dilakukan oleh Ibnu Khaldun pada awal di tahap ini adalah dengan melakukan pengulangan terhadap materi sebelumnya secara singkat. Hal ini dimaksudkan agar pemahaman peserta didik masih tetap melekat. Alasan lain Ibnu Khaldun menggunakan pola pengulangan di awal adalah untuk memperkuat hasil belajar pada tahapan pertama dan memperkuat pembelajaran pada tahap kedua.

Pada tahap ini, pendidik mulai memberikan perbedaan pendapat dan menjelaskannya kepada peserta didik dengan menyertai hal utama yang membedakannya. Hal ini dilakukan agar peserta didik mampu melihat dan menan ggapi perbedaan pendapat secara bijak.

Ahmad Tarmiji menambahkan bahwa "pada tahapan kedua ini, penjelasan mulai dirinci, diklasifikasikan dan difokuskan pada usaha membedakan materi-materi yang penting dan khusus serta titik-titik perbedaan yang mendasar yang dikemukakan oleh para ahli. ${ }^{17}$

\footnotetext{
${ }^{16}$ Ibnu Khaldun, Muqaddimah, Penerjemah MasturiIrhamdkk, (Jakarta: Pustaka Al-Ka utsar, 2011), h. 994

${ }^{17}$ Ahmad Tarmiji, Pemikiran Pendidikan Ibnu Khaldun,(Bogor, Edukasi Press, 2011), h. 148.
} 
Dengan demikian, pada tahapan kedua ini peserta didik diharapkan memiliki pemahaman yang lebih dalam mengenai materi tersebut. Selain itu, peserta didik juga diharapkan mampu membedakan materi ataupun istilah dari para ahli secara mendasar dengan bantuan pendidik. Dengan ini, peserta didik akan memiliki konsep sendiri dalam memahami materi yang diberikan.

Tahapan ketiga yaitu penyempurnaan dan kesimpulan(Takhallus) "Pada tahap akhir pelajar yang sudah terlatih itu harus diarahkan kepada masalah pokok yang dibahas. Kemudian diulang sekali lagi, diterangkan seagala yang rumit, yang kabur, atau sukar hingga memungkinkan ia mencapai keahlian yang sempurna". ${ }^{18}$

Dari pernyataan tersebut, dapat dikatakan bahwa tahapan ketiga inilah yang menjadi inti dalam pengajaran tersebut. Segala hal yang sulit ataupun yang belum jelas dikupas secara tuntas oleh pendidik. Lalu peserta didik yang sudah terlatih dengan berbagai macam istilah ataupun teori yang diberikan pada tahap satu dan dua, akan diarahkan padacontoh-contoh yang realistis sehingga mereka akan memaknai pelajaran tersebut.

Ibnu Khaldun mengungkapkan pengulangan materi pada tahap ketiga ini memiliki tujuan yang hampir sama dengan pengulangan pada tahap kedua, namun pengulangan pada tahap ini memiliki tujuan lainnya yaitu untuk mempersiapkan pemahaman peserta didik dalam menghadapi materi di tahapan ketiga. Hal ini dikarenakan pada tahap ini pendidik mengupas materi secara tuntas.

Menanggapi pola pengulangan Ibnu Khaldun, Bukhari Umar menjelaskan bahwa "dalam pelaksanaannya, pengulangan dapat dilakukan sebelum pemberian materi pelajaran dan dapat pula sesudah penyampaian bahan pelajaran. Pengulangan yang dilakukan sebelum penyampaian materi dimaksudkan untuk mengetahui tingkat penguasaan peserta didik sehubungan dengan materi yang akan diajarkan dan dapat pula untuk meningkatkan daya konsentrasi peserrta didik terhadap materi yang akan diajarkan. Pengulangan setelah pemberian materi dimaksudkan untuk mempertinggi penguasaan peserta didik terhadap materi pelajaran yang sudah diterima". ${ }^{19}$

\footnotetext{
${ }^{18}$ Ibnu Khaldun, Muqaddimah, Penerjemah MasturiIrhamdkk, (Jakarta: Pustaka Al-Ka utsar, 2011), h. 995.

${ }^{19}$ Bukhari Umar, Hadits Tarbawi, (Jakarta, Amzah, 2015), h. 143.
} 
Selain itu, Ahmad Tarmiji berpendapat bahwa yang diterangkan Ibnu Khaldun tersebut pada dasarnya mengandung arti pembelajaran yang efektif dan bermakna. Yakni sebuah pembelajaran yang mengindikasikan proses pemahaman, analisis-kritis dan keahlian yang disajikan secara bertahap. Dengan adanya tahapan-tahapan tersebut, akan memberi kesempatan kepada otak peserta didik untuk berfikir dan menyimpan informasi yang mereka peroleh dari pendidik. Disisi lain, dalam otak peserta didik akan terjalin semacam endapan memori pengetahuan yang tersusun secara teratur, dan pada akhirnya akan membentuk pengetahuan yang utuh. ${ }^{20}$

Dengan demikian, ketiga tahapan pembelajaran yang diungkapkan oleh Ibnu Khaldun tersebut merupakan satu kesatuan yang memiliki asas berkelanjutan. Namun, pendidik dapat mengurangi tahapan tersebut ataupun menambahkannya disesuaikan dengan kemampuan berfikir dan tingkat kesiapan mental peserta didik.

2. Metode Studi Banding (Rihlah)

Ibnu Khaldun mengatakan bahwa "bertemu langsung dengan orang-orang kompeten di bidang ilmu tertentu dan banyaknya guru sangat bermanfaat untuk memahami peristilahan yang dipakai, didasarkan pada apa yang ia lihat perbedaan cara yang mereka pakai. Ia tahu bahwa hal tersebut adalah lingkup pengajaran dan sebagai jalan untuk membangkitkan kekuatannya sehingga makin mantap dan dapat meluruskan pengetahuannya dan membedakan dengan yang lain. Juga untuk menguatkan nalurinya dengan cara bertemu langsung dan mempunyai banyak guru. Hal ini bagi orang yang dimudahkan oleh Allah SWT dalam mencari ilmu dan hidayah". ${ }^{21}$

Dari pernyataan tersebut diketahui bahwa untuk menyempurnakan pengetahuan serta pemahaman yang mendalam pada suatu cabang ilmu, Ibnu Khaldun menyarankan kepada peserta didik untuk melakukan lawatan atau studi banding kepada ahli ilmu tersebut. Hal ini dikarenakan mereka akan bertemu langsung dengan ahli atau pakar ilmu tersebut, sehingga akan mendapat pengalaman-pengalaman maupun istilah-istilah baru yang akan mengantarkan wawasan pengetahuan dan keilmuan peserta didik tersebut menjadi semakin luas.

\footnotetext{
${ }^{20}$ Ahma d Tarmiji, Pemikiran Pendidikan Ibnu Khaldun,(Bogor, Edukasi Press, 2011), h. 150.

${ }^{21}$ Ibnu Khaldun, Muqaddimah, Penerjemah MasturiIrhamdkk, (Jakarta: Pustaka Al-Ka utsar, 2011), h. 1.009 .
} 
Metode studi banding ini dilakukan untuk menyempurnakan pemahaman peserta didik yang terlebih dahulu mendapatkan pengalaman belajar dalam metode gradual dan pengulangan. Selain itu, metode ini juga diharapkan menumbuhkembangkan peserta didik dalam mencapai aktualisasi diri mereka. Alasan lain pendidik melakukan metode tersebut adalah demi memberikan kebebasan kepada peserta didik untuk menemui para ahli ilmu serta untuk memenuhi hasrat belajar mereka dan sebagai penyempuma pemahaman dengan cara observasi langsung.

Namun, alangkah baiknya jika metode studi banding tersebut diterapkan oleh pendidik ketika para peserta didik telah mampu menemukan konsep pemahamannya mengenai materi ataupun pelajaran tersebut padametode gradual dan pengulangan. Jika pendidik langsung mengarahkan peserta didik untuk studi banding tanpa adanya pemberian pemahaman terlebih dahulu kepada mereka, maka hal itu akan menyebabkan peserta didik menjadi semakin tidak paham ketika menimba ilmu dari ahlinya tersebut.

Dengan demikian, jelaslah metode studi banding atau metode rihlah yang diungkapkan oleh Ibnu Khaldun merupakan salah satu metode pengajaran yang mengutamakan nilai-nilai humanis terhadap peserta didik. Hal itu dikarenakan pendidik memberikan kebebasan kepada peserta didik untuk memenuhi hasrat menuntut ilmu serta membangun pemahaman dan wawasan mereka dalam mencapai aktualisasi diri.

\section{Metode Diskusi (Munadzarah)}

Ibnu Khaldun mengatakan bahwa kadang pemikiran diharuskan berdebat untuk dapat memahami kata-kata atau menemukan kesamaan-kesamaan petunjuk melalui perdebatan tersebut untuk membuka kekusutan pemikiran dan ketidakjelasan. Jika pikiran pelajar kusut, maka pemahamannya akan gagal. Hampir dipastikan tidak ada yang dapat melewati petualangan tersebut, kecuali mereka yang telah mendapat petunjuk Allah SWT". ${ }^{22}$

Dari pernyataan diatas, Selain menggunakan motode tadrij dan takrir serta metode studi banding atau rihlah, Ibnu Khaldun juga menaruh perhatian yang sangat besar terhadap metode diskusi (munadzarah) yang terutama dalam mengimplementasikan ide-ide peserta didik, yaitu dengan memberikan masalah kepada peserta didik dan mendorong mereka untuk mencari solusi terbaik. Dengan

\footnotetext{
${ }^{22}$ Ibnu Khaldun, Muqaddimah, Penerjemah MasturiIrhamdkk, (Jakarta: Pustaka Al-Ka utsar, 2011), h. 999.
} 
memberikan masalah-masalah ilmiah kepada peserta didik, pendidik memberikan ruang diskusi kepada mereka untuk mengekspresikan pendapat ataupun argumen demi mencari solusi terbaik dari permasalahan yang diberikan.

Adapun masalah-masalah ilmiah yang dimaksud Ibnu Khaldun adalah masalah yang ditemukan dan biasa ditemui dalam kehidupan sehari-hari sehingga perlu pembahasan dengan mengumpulkan ide atau gagasan oleh banyak peserta didik demi mendorong dalam mencapai pemahaman yang utuh dan menumbuhkan pengertian.

Meski demikian, Menurut Ibnu Khaldun metode ini merupakan metode yang sulit dilakukan oleh para peserta didik. Mengenai hal ini, Ibnu Khaldun memberikan cara-cara yang harus dilakukan oleh peserta didik adalah "Pertama-tama yang harus dilakukan adalah memahami bentuk tulisan yang menunjukkan kata-kata yang dapat diucapkan. Ini merupakan langkah yang paling ringan, Langkah selanjutnya adalah memahami aturan-aturan dalam urutan-urutan pengertian kata untuk mengambil kesimpulan dari premis-premis yang sudah populer dalam ilmu logika. Kemudian pengertian tersebut dimurnikan atau diabstraksikan dalam pemikiran dan menghadapkannya pada rahmat Allah SWT dan anugerah-Nya". ${ }^{23}$

Dalam metode diskusi (munadzarah)ini, Ibnu Khaldun menekankan pentingnya membimbing dan memberi wewenang kepada peserta didik untuk mengungkapkan pendapat mereka serta memberi kesempatan bersama untuk saling membantu, menghargai serta bekerja sama demi menemukan solusi bersama.

Ibnu Khaldun juga mengungkapkan secara tersirat bahwa metode diskusi (munadzarah) merupakan salah satu metode yang ampuh dalam mengembangkan psikomotorik peserta didik. Hal ini dikarenakan metode diskusi dapat melahirkan daya kritis dan keaktifan peserta didik dalam pembelajaran dengan cara melatih dan memberanikan diri dalam mengungkapkan pendapatnya dalam sebuah diskusi.

Selain itu, metode ini juga diharapkan mampu melatih sikap peserta didik untuk menghargai pendapat orang lain, melatih keberanian dalam mengungkapkan ataupun mempertahankan pendapat, dan memberi kesempatan yang sama terhadap peserta didik lainnya untuk mengungkapkan pendapatnya.

\footnotetext{
${ }^{23}$ Ibnu Khaldun, Muqaddimah, Penerjemah Masturi Irhamdkk, (Jakarta: Pustaka Al-Ka utsar, 2011), h. 998-999.
} 
Dari ungkapan tersebut, Ibnu Khaldun juga membedakan peserta didik dalam menerapkan metode munadzarah, tadrij dan takrir serta rihlah. Metode tadrij dan takrir ditujukan kepada peserta didik yang masih pemula dan butuh bimbingan lebih dari pendidik terutama dalam memberikan pemahaman berfikir dan menanamkan pemahaman yangg utuh pada mereka. Oleh karena itu, tugas pendidik dalam hal ini tidak terbatas hanya sebagai fasilitator, tetapi juga sebagi mediator serta memonitoring pemahaman mereka.

Sedangkan dalam metode studi banding (rihlah), tugas pendidik hanya sebatas memonitoring peserta didik mengenai apa yang mereka dapatkan dari ahli ilmu tersebut serta mengetahui perbedaan sebelum melakukan studi banding dan setelah melakukannya

Ketika dalam metode munadzarah, peserta didik diharapkan memiliki pemahaman yang sempurna, kematangan berfikir, serta wawasan yang luas, sehingga peran pendidik pada metode ini hanya sabatas sebagai fasilitator bagi mereka. Dengan demikian, pendidik memiliki tugas masing-masing dalam menumbuhkan dan mengembangkan potensi peserta didik sesuai dengan kebutuhannya.

Jelaslah metode munadzarah yang dikemukakan oleh Ibnu Khaldun merupakan salah satu metode pengajaran yang mengutamakan nilai-nilai humanis terhadap peserta didik. Diantara aspek humanis yang terdapat dalam metode diskusi antara lain sebagai berikut: (a). Metode munadzarah melibatkan semua peserta didik secara langsung dalam proses pembelajaran, (b). Setiap peserta didik dapat menguji tingkat pengetahuannya masing-masing, (c). Metode munadzarah dapat menumbuhkan dan mengembangkan cara berpikir dan sikap ilmiah peserta didik, (d). Dengan mengajukan dan mempertahankan pendapatnya dalam diskusi, diharapkan para peserta didik dapat memperoleh kepercayaan akan kemampuan diri sendiri, (e). Metode munadzarah dapat menunjang usaha-usaha pengembangan sikap sosial dan sikap demokratis para peserta didik, (f). Metode munadzarah juga dapat melatih kemampuan peserta didik dalam berkomunikasi terhadap orang lain.

Dengan demikian metode ini memberi peserta didik tanggung jawab untuk mempelajari masalah dan menemukan solusi bersama-sama. Metode ini pun dapat memberi pesan moral kepada peserta didik yaitu agar mereka memiliki sikap tenggang 
rasa dan rasa saling membantu dengan temannya serta mampu melihat perbedaan pendapat sebagai jalan untuk menyelesaikan permasalahan bersama.

Dari ketiga metode diatas, Ibnu Khaldun mengungkapkan bahwa cara terbaik bagi pendidik dalam menggunakan ketiga metode tersebut kepada peserta didik adalah dengan menyesuaikan kemampuan dan kebutuhan mereka. Bagi peserta didik yang masih pemula, penggunaan metode gradual dan pengulangan adalah yang terbaik. Sedangkan untuk memenuhi hasrat dan keinginan peserta didik dalam menguasai ilmu secara mendalam serta untuk mencapai pemahaman yang utuh dan sempurna, maka metode studi banding (rihlah) yang dibutuhkan. Apabila ingin menghadapkan peserta didik dengan masalah-masalah ilmiah dan butuh penyelesaian atau solusi bersama, maka sebaiknya pendidik menggunakan metode diskusi (munadzarah). Ketiga metode ini dilakukan agar peserta didik mampu mencapai aktualisasi diri ataupun malakah mereka masing-masing.

\section{KESIMPULAN}

Berdasarkan konsep pendidikan terutama mengenai pendidik dan metode pembelajaran, pemikiran Ibnu Khaldun mengenai pendidik dan metode pembelajaran yang ada dalam kitab Muqaddimah dapat dikategorikan sebagai pendidik dan metode pembelajraan yang humanis. Hal ini berdasarkan beberapa hal sebagai berikut :

Dalam pandangan Ibnu Khaldun, seorang pendidik yang humanis haruslah dapat memberi pengajaran sesuai tingkat kesiapan (isti'dad) pemahaman berfikir dan mental serta kesiapan peserta didik demi menumbuhkan malakah mereka. Pendidik yang humanis juga harus mampu memaksimalkan potensi peserta didik dengan menanamkan dan menumbuhkan pemahaman yang sempurna (malakah). Selain itu, seorang pendidik juga harus memiliki sifat lemah lembut dan kasih sayang (almulayanah) dalam memberikan pengajaran terhadap peserta didik

Dalam metode pembelajaran yang humanis, pendidik harus mengoptimalkan seluruh potensi peserta didi agar dapat berpikir kritis dan mengembangkan kemampuannya. Adapun metode-metode pembelajaran yang diungkapkan oleh Ibnu Khaldun dan sesuai dengan metode pembelajaran humanis adalah metode dengan pola gradual (tadrij) dan pengulangan (takrir). Dalam pola ini Ibnu Khaldun membagi pengajaran kepada tiga tahapan yaitu Sabilul Ijmal, Syarhul Bayan dan Takhallus. Ibnu 
Khaldun juga mengemukakan pentingnya metode lawatan (rihlah) kepada pendidik yang memiliki keahlian tertentu demi memaksimalkan pemahaman peserta didik tersebut. Terakhir, Ibnu Khaldun menganjurkan metode diskusi (munadzarah) demi melatih keaktifan berbicara peserta didik dalam mengemukakan pendapat mereka.

\section{DAFTAR PUSTAKA}

Tarmiji Ahmad, Pemikiran Pendidikan Ibnu Khaldun, Bogor: Edukasi Press, 2011. Nurul Ahmad Kawakib, Islam Moderat, Malang: UIN-Maliki Press, 2016.

Siregar Eveline dan Hartini Nara, Teori Belajar dan Pembelajaran, Bogor: Ghalia Indonesia, 2014, cet. III.

Gunawan Imam, Metode Penelitian Kualitatif, Jakarta: Bumi Aksara, 2013, cet. I.

Bungin Burhan, Penelitian Kualitatif: Komunikasi, Ekonomi, Kebijakan Publik, dan Ilmu Sosial Lainnya, Jakarta: Kencana, 2008, Cet. III.

Nata Abuddin dan Fauzan (eds), Pendidikan dalam Perspektif Hadits, Ciputat: UIN Jakarta Press, 2005, cet. I.

Ibnu Khaldun, Muqaddimah, Penerjemah Masturi Irham dkk, Jakarta: Pustaka AlKautsar, 2011.

Nata Abuddin, Filsafat Pendidikan Islam, Jakarta: Logos Wacana Ilmu, 1997, cet. I. 
Konsep Pendidik dan Metode Pembelajaran yang Humanis Menurut Ibnu Khaldun

Vol. 6 No. 1. April 2020

Halaman $97-114$ 